Churikanova, O. and Lysenko, M. (2019). "Optimization management of investment for coal mines based on neural network model", Management and entrepreneurship: trends of development, 3(09), pp. 33-51. DOI: https://doi.org/10.26661/2522-1566/2019-3/09-03

\title{
MANAGEMENT
}

Received:

UDC: 330.322.4

17 June, 2019

1st Revision:

17 July, 2019

DOI https://doi.org/10.26661/2522-1566/2019-3/09-03

Accepted:

22 July, 2019

\section{OPTIMIZATION MANAGEMENT OF INVESTMENT FOR COAL MINES BASED ON NEURAL NETWORK MODEL}

\author{
Olena Churikanova \\ Dnipro University of Technology \\ Dnipro, Ukraine \\ ORCID: 0000-0001-5703-2271
}

\author{
Maryna Lysenko \\ Zaporizhzhia National University \\ Zaporizhzhia, Ukraine \\ ORCID: 0000-0003-1811-9918
}

*Corresponding author email: lysenko.maryna0108@gmail.com

Abstract

The main objective of the paper is to develop a system of economic and mathematical models for managing the investment activity of the coal mining enterprise, including improving the principles and methods for analyzing the profitability of investment projects and the optimal allocation of investments. Therefore, the article addressing the following issues:

- $\quad$ to determine the objectives of investment activity in coal mining enterprises;

- $\quad$ to systematize and identify statistically significant factors influencing investment activity in coal mining enterprises - affecting investment in coal mines;

- $\quad$ to form an economic-mathematical model for determining the amount of money that a coalmining enterprise can allocate to investing;

- $\quad$ to form an economic-mathematical model for determining the enterprises profit as a result of the investment project implementation;

- to demonstrate expediency and perspective of the complex of developed model's implementation, to check their practical efficiency;

With the help of neural networks, a model was built based on 12 kinds of investment ( 9 kinds of investments into equipment, capital investment, portfolio investment, intangible assets investments) which are the most typical for a coal-mining enterprise.

The method of optimization of investment allocation on a coal mine was developed, which, in contrast to the existing ones, determines the optimal investment volume, which helps to maximize profits for 12 investment models.

As a result the method of optimization of investment allocation on a coal mine was developed, which, in contrast to the existing ones, determines the optimal investment volume, which helps to maximize profits for 12 investment models.

Keywords: coal industry, investments, statistically significant factors, economic and mathematical models, neural networks, optimization.

JEL Classification: C45, E22, L72.

\section{INTRODUCTION}

Nowadays an insignificant investment activity in the Ukrainian coal-mining industry can be noticed. Therefore, in the period of limited investment resources, the effectiveness of their rational use comes to the fore. To solve such tasks, an improved methodology for optimal distribution of 
limited investment resources is needed, which is tailored specifically to the coal mining industry and takes into account those characteristics that can influence the efficiency of investments. It indicates the relevance of the problems that are posed and solved in the research.

The questions of investment activity are studied by many scientists all over the world, but their research does not exhaust the whole complex of issues related to this problem.

In 1959, the first official standard methodology - the definition of the economic efficiency of capital investments, which was the subject of mandatory application in all branches of the national economy, was approved in the USSR.

Instead of the old methods of calculating the efficiency of investments that were used during a planned economy, the methods of calculating the economic efficiency of investments that were used in industrialized countries were borrowed at the initial stage of Ukraine's restructuring.

But, despite the fact that the methods of assessments of investment processes as well as the conditions for their application are defined and worked out by international practice of developed countries, one should not rely on their versatility and perfection. Many Ukrainian economists and scientists believe that it is unsuitable for use without a thorough study of specific conditions and taking into account the specifics of socio-economic processes that are characteristic for Ukrainian society (Pavlenko, 2017; Maidukova, 2010; Amosha et al., 1999).

At present, the economic justification of investment projects in mines is a multidimensional space consisting of natural and cost indicators (Pavlenko, 2017).

In summarizing all the approaches to optimizing the methods of determining the effectiveness of investment projects, we see that they all consist in changing the interpretation of the main indicators of determining the effectiveness of investment and in modifying these indicators, as well as in changing the set of indicators involved in assessing the effectiveness of the investment project (Amosha et al., 1999; Vorontsovsky, 2016; Purayev, 2015; Damodaran, 2016; Bryntsev, 2017; Stanislavchik, 2017; Stanislavchik, 2017). The method proposed for use in any enterprise. Consequently, they do not take into account the peculiarities of the functioning of the structure to which they are applied.

In the process of creating the optimal investment plans for mining companies it is nessesary to take into account all parts of the mine. The financial performance of the mine and its investment needs affects a large number of factors - from the financial and economic to geological conditions. Therefore, the determination of factors that are directly dependent on the performance of investment activities is relevant (Sally et al., 2002; Trifonova et al., 2005).

\section{METHODOLOGY}

Setting objectives. It is necessary to form a complex investment project, the realization of which will have a positive impact on the profit increase of coal mining enterprises. Investments are presented in 12 types most characteristic for coal-mining enterprises of Ukraine:

A. material investments: investments in mine winders; investments in fan units; investments in compressor units; investments in pump stations; investments in transport installations; investments in decontamination plants; investments in thermal power units; investments in the mine surface plant; investments in electrical installations; other capital investments;

B. financial investments: portfolio investments;

C. intangible investments: training, research and development.

Regarding the source of the project's investment, the task is that solved within the framework of this work involves increasing the efficiency of the use of the company's own funds.

Solving this task will answer the following questions:

1. What is the amount of money that can be allocated to investing in coal mining enterprises? 
Churikanova, O. and Lysenko, M. (2019). "Optimization management of investment for coal mines based on neural network model", Management and entrepreneurship: trends of development, 3(09), pp. 33-51. DOI: https://doi.org/10.26661/2522-1566/2019-3/09-03

2. What level of profit will be obtained by a coal-mining enterprise in the case of realization of a particular investment project?

3. How to allocate between the 12 types of investment funds allocated for investing in order to maximize profits?

Stages of solving the problem:

Stage 1. Development of an economic-mathematical model for determining the volume of investment in a coal-mining enterprise.

The purpose of the model is to determine the amount of money that a coal-mining enterprise can allocate to investing at its own expense.

Stage 2. Development of the economic-mathematical model for determining the profit of a coal-mining enterprise depending on the volume of investments by means of neural networks.

The purpose of the model is to determine how the level of investment affects the profit of the coal mining enterprise.

Stage 3. Development of a model for determining the optimal volume of investment in a coal mining enterprise. Make a breakdown of investments by 12 types of investment, which will help to maximize the profit of the coal mining enterprise. The economic-mathematical model for determining the optimal amount of investment combines the results of the work of the models mentioned in the previous two stages.

Stage 4. Verification of the model of determining the optimal investment volumes using the classical methodology for evaluating the effectiveness of investment projects.

\section{Data collection}

An analysis of literary sources on the issue of identifying factors (Pavlenko, 2017; Maidukova, 2010; Amosha et al., 1999; Vorontsovsky, 2016; Purayev, 2015; Damodaran, 2016; Bryntsev, 2017; Stanislavchik, 2017; Stanislavchik, 2017; Sally et al., 2002; Trifonova et al., 2005) that have an impact on investment activity has revealed many indicators, proposed as priority, and which refer to specific directions.

Data on investment activity in mines for 13 of their associations was collected, each of which consists of 3 to 7 privately owned mines, for the period of $2003-2011$. The total amount of the data in the table is 132 lines and 12 columns, so it will not be posted here.

To verify the influence of the selected factors, a correlation analysis was performed on the collected data. Correlation coefficients are presented in the form of a triangular matrix in table 1.

Table 1

\section{Correlation matrix}

\begin{tabular}{|c|c|c|c|c|c|c|c|c|c|c|c|c|c|c|c|c|}
\hline & $\mathrm{X} 1$ & $\mathrm{X} 2$ & $\mathrm{X} 3$ & $\mathrm{X} 4$ & $\mathrm{X} 5$ & $\mathrm{X} 6$ & $\mathrm{X} 7$ & $\mathrm{X} 8$ & $\mathrm{X} 9$ & $\mathrm{X} 10$ & $\mathrm{X} 11$ & $\mathrm{X} 12$ & $\mathrm{X} 13$ & $\mathrm{X} 14$ & $\mathrm{X} 15$ & $\mathrm{X} 16$ \\
\hline 0 & 1 & 2 & 3 & 4 & 5 & 6 & 7 & 8 & 9 & 10 & 11 & 12 & 13 & 14 & 15 & 16 \\
\hline$X_{1}$ & 1,0 & & & & & & & & & & & & & & & \\
\hline$X_{2}$ & 0,4 & 1,0 & & & & & & & & & & & & & & \\
\hline$X_{3}$ & 0,1 & 0,0 & 1,0 & & & & & & & & & & & & & \\
\hline$X_{4}$ & 1,0 & 0,4 & 0,1 & 1,0 & & & & & & & & & & & & \\
\hline$X_{5}$ & 0,3 & 0,7 & 0,1 & 0,2 & 1,0 & & & & & & & & & & & \\
\hline$X_{6}$ & 0,3 & 0,8 & 0,0 & 0,3 & 0,5 & 1,0 & & & & & & & & & & \\
\hline
\end{tabular}

Table 1 continuation on the next page 
Table 1 continuation

\begin{tabular}{|c|c|c|c|c|c|c|c|c|c|c|c|c|c|c|c|c|}
\hline 0 & 1 & 2 & 3 & 4 & 5 & 6 & 7 & 8 & 9 & 10 & 11 & 12 & 13 & 14 & 15 & 16 \\
\hline$X_{7}$ & 0,2 & 0,8 & 0,0 & 0,3 & 0,4 & 0,9 & 1,0 & & & & & & & & & \\
\hline$X_{8}$ & 0,3 & 0,8 & 0,1 & 0,3 & 0,5 & 0,9 & 0,8 & 1,0 & & & & & & & & \\
\hline$X_{9}$ & 0,3 & 0,6 & 0,1 & 0,3 & 0,6 & 0,7 & 0,7 & 0,5 & 1,0 & & & & & & & \\
\hline$X_{10}$ & 0,3 & 0,8 & 0,1 & 0,3 & 0,5 & 0,9 & 0,8 & 0,9 & 0,6 & 1,0 & & & & & & \\
\hline$X_{11}$ & 0,3 & 0,9 & 0,1 & 0,3 & 0,6 & 0,7 & 0,6 & 0,7 & 0,4 & 0,6 & 1,0 & & & & & \\
\hline$X_{12}$ & 0,3 & 0,8 & 0,0 & 0,4 & 0,3 & 0,8 & 0,8 & 0,8 & 0,5 & 0,8 & 0,6 & 1,0 & & & & \\
\hline$X_{13}$ & 0,3 & 0,9 & 0,1 & 0,4 & 0,6 & 0,7 & 0,6 & 0,7 & 0,4 & 0,7 & 0,9 & 0,6 & 1,0 & & & \\
\hline$X_{14}$ & 0,3 & 0,9 & 0,0 & 0,3 & 0,6 & 0,7 & 0,6 & 0,7 & 0,4 & 0,7 & 0,9 & 0,6 & 0,9 & 1,0 & & \\
\hline$X_{15}$ & 0,4 & 0,3 & 0,2 & 0,4 & 0,1 & 0,2 & 0,2 & 0,2 & 0,3 & 0,3 & 0,2 & 0,4 & 0,3 & 0,2 & 1,0 & \\
\hline$X_{16}$ & 0,3 & 0,4 & 0,1 & 0,4 & 0,3 & 0,3 & 0,2 & 0,4 & 0,4 & 0,4 & 0,4 & 0,3 & 0,4 & 0,3 & 0,6 & 1,0 \\
\hline
\end{tabular}

Symbols in the table: $X_{1}$ - Income; $X_{2}$ - Profit; $X_{3}$ - Average wholesale price; $X_{4}$ - Coal production volume; $X_{5}$ - Mine winders; $X_{6}$ - Fan units; $X_{7}$ - Compressor units; $X_{8}$ - pump stations; $X_{9}$ - Transport installations; $X_{10}$ - Decontamination plants; $X_{11}$ - Thermal power units; $X_{12}$ - Mine surface plant; $X_{13}$ - Electrical installations; $X_{14}$ - Other capital investments; $X_{15}$ - Investments in the financial portfolio; $X_{16}$ - Intangible investments.

As can be seen from the table, factors such as average wholesale price, coal production volume, investment in the financial portfolio and intangible investments almost do not affect profit. Therefore, these factors were excluded from the general data array when creating coal mine investment models.

In addition to the financial indicators, production parameters were added to the input factors, such as: residual reserves in million tonnes, average geological thickness of the coal seams, maximum operating depth in meters, length of mine workings in $\mathrm{km}$, incident angle of the coal seams, production (designed) capacity in million tonnes per year. As well as physical and mechanical parameters of coal produced at these mines: average ash content $\%$, average moisture content $\%$, average sulfur content $\%$.

\section{Neural network model construction}

At the stage of making a decision on the appropriateness of an investment project, there are two main questions:

1) what volume of investments will be optimal for a particular investment project in the given parameters of the enterprise - profit, production volumes, geological factors;

2) what will be the economic effect of a certain amount of investment, that is, the level of profit.

To answer the above questions, building a model by means of neural networks is required.

The most acceptable in this case is the choice of a two-layer perceptron and an algorithm for the reverse error propagation.

This type of neural networks is well-researched and described in the scientific literature. A similar network can simulate functions of almost any degree of complexity, and the number of layers and the number of elements in each layer determine the complexity of the function.

As a function of activation, the sigmoid was chosen, which is very commonly used for multilayer perceptrons and in other networks with continuous signals: 
Churikanova, O. and Lysenko, M. (2019). "Optimization management of investment for coal mines based on neural network model", Management and entrepreneurship: trends of development, 3(09), pp. 33-51. DOI: https://doi.org/10.26661/2522-1566/2019-3/09-03

where:

$$
O U T=\operatorname{sigm}(N E T)=\frac{1}{1+e^{-N E T}}
$$

OUT - network output

NET - the weighted average amount obtained in the first stage of calculating the output value of the neuron.

Sigmoid function is often used for multilayer perceptrons and other networks with continuous signals, because it has such positive qualities as:

- smoothness;

- continuity of function;

-the continuity of the first derivative, which allows to train the network.

In order to increase the adequacy of the model before the training of the perceptron, the input and output data were centered and normalized according to the following rule:

- updated standardization of input data:

$$
x=\frac{X-m_{x}}{8 \sigma_{x}}+\frac{1}{2}
$$

where:

$$
\begin{aligned}
& m_{X}-\text { average value } X ; \\
& \sigma_{X}-\text { mean square deviation } X .
\end{aligned}
$$

The obtained value belonged range of -4 to 4 with a probability of 0.99 . In order to obtain data in the range from 0 to 1 , assuming that the distribution law for the factors $\mathrm{X}$ and $\mathrm{Y}$ is normal, the following formulas have been made:

- updated standardization of input data:

where:

$$
y=\frac{Y-m_{y}}{8 \sigma_{y}}+\frac{1}{2}
$$

$$
\begin{aligned}
& m_{Y}-\text { average value } Y ; \\
& \sigma_{Y}-\text { mean square deviation } Y \text {. }
\end{aligned}
$$

The training error was calculated using the formula of the cumulative quadratic deviation between the desired (y) and the actual output at the network (OUT) signals for all sets of the training set:

$$
E=\frac{1}{2} \sum_{k=1}^{P}\left(y_{k}-O U T_{k}\right)^{2},
$$

where:

$E$ - total squared error (training criterion),

$P$ - number of examples in the training set,

$y_{k}$-desired output value,

OUT - really got the output of the network,

$k$ - example number.

Since all calculations of weighting factors were made in the integral system for complex statistical analysis and processing in the Windows environment - Neuro Excel, all further explanations for the calculations are given in the terminology of this particular application. 


\subsection{Modeling of the investment volume}

For this modeling, a dual-layer neural network was built that has 11-3-12 architecture (number of inputs - the number of neurons in the first layer - the number of outputs) and the following parameters:

a number of layers without input (Number of layer) $=2$;

a number of inputs (Number of inputs) $=11$;

a number of neurons in the first layer (Layer1, neurons) $=3$;

an order of non-linearity of the first layer (order) $=1$;

a type of output function of the first layer (function) = sigmoid;

a number of neurons in the second layer (neurons) $=12$;

an order of non-linearity of the second layer (order) $=1$;

a type of output function of the second layer (function) $=$ linear.

The neural network was trained using the following settings: the nature of the test sample is set to Random, because the random selection of the test set is the most significant for the approximation problems; initial error of elements (Initial delta) $=0,1$; minimum error (Minimal delta $)=1 \times 10-8$; maximum error $($ Maximal delta $)=10$; decrease step $\mathrm{Nu}(-)=0,5$; increment step $\mathrm{Nu}(+)=1,2$.

At the first step, the training was completed when it reached the number of 1000 epochs. The training error 0.07 was received, which was stabilized when the mark reached 886 epochs. Small deviations of the real data line from the data provided by the network were obtained graphically. In other words, the network produces the same set of data that was given as the input with a possible error of no more than $1 \%$. If the network is not trained to make accurate predictions on the numerical values at which the training was conducted, it will lead to significant errors in prediction on a new selection of numerical values (fig. 1).

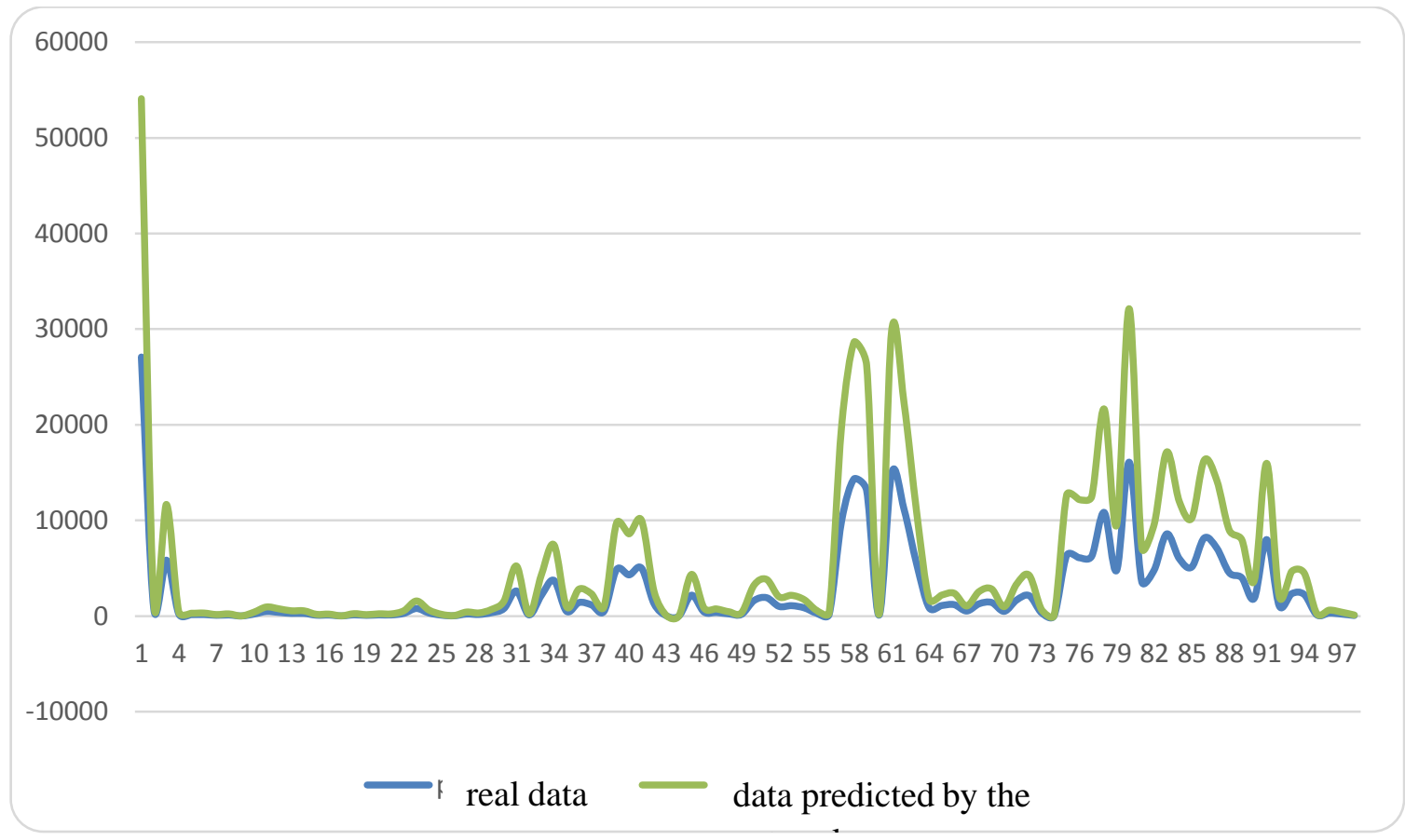

Fig. 1. The result of the neural network training - the line of real data and the line of the network Source: compiled by authors response 
Churikanova, O. and Lysenko, M. (2019). "Optimization management of investment for coal mines based on neural network model", Management and entrepreneurship: trends of development, 3(09), pp. 33-51. DOI: https://doi.org/10.26661/2522-1566/2019-3/09-03

The authors conducted an experiment to study the network with the use of other architectures. During the experiment it was determined that the architecture network 11-3-12 has the slightest error and better predictive capabilities.

The work of such a network is described by the formula (5):

$$
O U T=\operatorname{sigm}\left(\lambda_{2} \sum_{j=1}^{3}\left(\operatorname{sigm}\left(\lambda_{1} \sum_{i=1}^{11} x_{i} w_{i j}^{1}\right) \cdot w_{j k}^{2}\right)\right)
$$

where:

$O U T$ - investments in mine winders; investments in fan units; investments in compressor units; investments in pump stations; investments in transport installations; investments in decontamination plants; investments in thermal power units; investments in the mine surface plant; investments in electrical installations; other capital investments; portfolio investments; intangible investments;

$x_{i}$ - profit; volume of production; average ash content of coal; average moisture content of coal; average sulfur content; residual reserves in million tonnes; average geological thickness of the coal seams; maximum operating depth in meters; length of mine workings in km; incident angle of the coal seams; production (designed) capacity in million tonnes per year.

$w_{i j}^{1}$ - the weight coefficient of i-th input of the neuron number $j$ in the $l$ layer;

$w_{i k}^{2}$ - the weight coefficient of $j$-th input of the neuron number $\kappa$ in the 2 layer $i \lambda>0-$ the steepness coefficient of a continuous function $f$ (net), approximate net $=0.5$.

The total number of scales of the 11-3-12 network is 69 . Based on the fact that the sample size is 132 , the neuron-based network is capable of modeling.

\subsection{Modeling the dependence of the profit from investment}

For the construction of the neural network, a statistical sample of 132 data units from mines were used, where 131 data units for the period of 2003-2011 were used at the stage of neural network training and data on the OJSC "Pavlogradvygillya" for 2012 was used as data for testing of network forecasting properties, as in the previous sub-paragraph. The purpose of this model of the neural network will be to determine the profit of mines, taking into account a certain level of investment by type of investment.

Unlike the model developed in the previous subsection, the input data here will be investments by type (material, financial, intangible). Also, the geological factors were added, including the main characteristics of coal mined. The profits of the coal mining enterprise are taken as input data.

To solve this problem, a two-layer perceptron was developed, where the input was the value of investment volumes according to the enterprises, geological factors and technical properties of coal, and the forecast on the profit as an output parameter was made. The construction of the neural network was carried out according to the algorithm used in paragraph 2.2.1.

To determine the significance of the inputs used for the given outputs, the satisfactory ratio between average and dispersion was calculated:

$X 1=1,67 / 0,13=12,8$.

At the first stage, a two-layer neural network was constructed with 21-3-1 architecture (the number of inputs - the number of neurons in the first layer - the number of outputs) and the following parameters:

a number of layers without input (Number of layer) $=2$;

a number of inputs (Number of inputs) $=21$;

a number of neurons in the first layer (Layer1, neurons) $=3$;

an order of non-linearity of the first layer (order) $=1$; 
a type of output function of the first layer (function) = sigmoid;

a number of neurons in the second layer (neurons) $=1$;

an order of non-linearity of the second layer (order) $=1$;

a type of output function of the second layer (function) $=$ linear.

The neural network was trained using the following settings: the nature of the test sample is set to Random, because the random selection of the test set is the most significant for the approximation problems; initial error of elements (Initial delta) $=0,1$; minimum error (Minimal delta $)=1 \times 10-8$; maximum error $($ Maximal delta $)=10$; decrease step $\mathrm{Nu}(-)=0,5$; increment step $\mathrm{Nu}(+)=1,2$.

At the first step, the training was completed when it reached the number of 1000 epochs. The training error 0.01, was received, which was stabilized when the mark reached 728 epochs. Small deviations of the real data line from the data provided by the network were obtained graphically. In other words, the network produces the same set of data that was given as the input with a possible error of no more than $1 \%$. If the network is not trained to make accurate predictions on the numerical values at which the training was conducted, it will lead to significant errors in prediction on a new selection of numerical values (fig. 2).

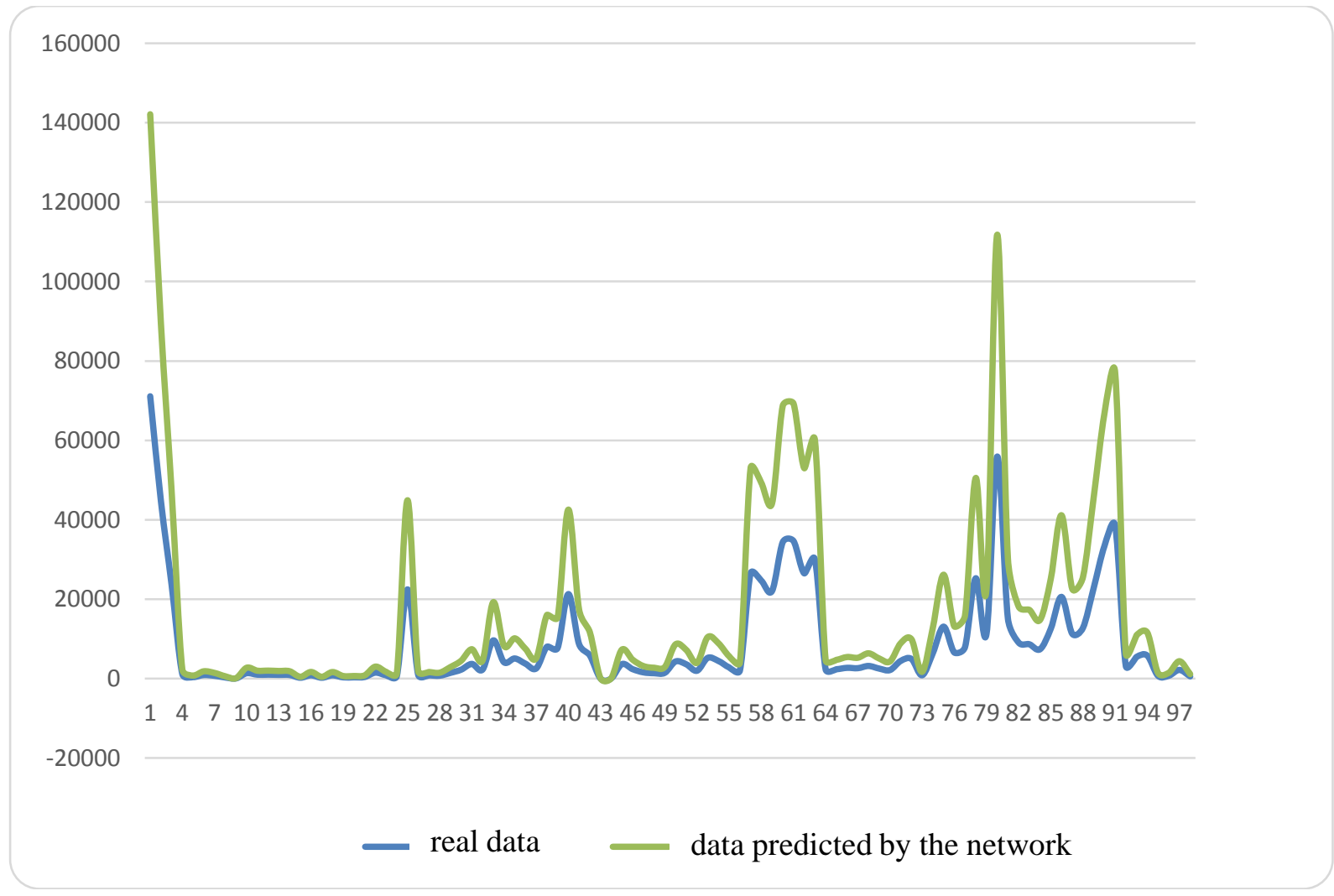

Fig. 2. The result of the neural network training - the line of real data and the line of the network response

Source: compiled by authors

The authors conducted an experiment to study the network with the use of other architectures. During the experiment it was determined that the architecture network 21-3-1 has the slightest error and better predictive capabilities.

The work of such a network is described by the formula (6):

$$
O U T=\operatorname{sigm}\left(\lambda_{2} \sum_{j=1}^{3}\left(\operatorname{sigm}\left(\lambda_{1} \sum_{i=1}^{21} x_{i} w_{i j}\right) w_{j}\right)\right.
$$


Churikanova, O. and Lysenko, M. (2019). "Optimization management of investment for coal mines based on neural network model", Management and entrepreneurship: trends of development, 3(09), pp. 33-51. DOI: https://doi.org/10.26661/2522-1566/2019-3/09-03

where:

$x_{i}$ - input factors: investments: mine winders; fan units; compressor units; pump stations; transport installations; decontamination plants; thermal power units; mine surface plant; electrical installations; other capital investments; portfolio investments; intangible investments; average ash content of coal; average moisture content of coal; average sulfur content; residual reserves in million tonnes;

geological factors: average geological thickness of the coal seams; maximum operating depth in meters; length of mine workings in $\mathrm{km}$; incident angle of the coal seams; production (designed) capacity in million tonnes per year.

$w_{i j}$ - weight coefficient of the $i$-th input of the neuron number $j$ in the first layer

$w_{j}$ - weight coefficient of $j$-th input of neuron of the second layer,

OUT - output signal of the neural network - profits of the coal mining enterprise,

$\lambda 1$ and $\lambda 2$ - coefficients of steepness of the sigmoids of the first and second layers, $\lambda 1$ and $\lambda 2$ were approximately 0.5 .

Thus, the total number of scales of the 21-3-1 network is 66 . Based on the fact that the sample size is 132 , the neuron-based network is capable of modeling.

\subsection{Investigation of predictive properties of the obtained models}

In order to establish the modeling properties of neural network models developed in paragraphs 2.2.1 and 2.2.2, testing of the training quality using test set is required.

At this stage, the generated primary model is further tested as a prognostic tool on a series of test data that were not included in the training sample. In this way, the test set should be different from the training one. To this end, data on the performance of OJSC "Pavlogradvygillya" for 2012, which was not taken for the neural networks training, was used.

To test the "Modeling the volume of investment" neural network, developed in paragraph 2.2.1. the inputs of the network were prepared, among which there are the values of profit, volumes of production, technical properties and geological factors of coal at OJSC "Pavlogradvygillya" in 2012. With the help of the NeuroExcel add-in, based on the already trained neural network, the modeled output data was received, including the volumes of investment by types presented in table 2.

Table 2

Results of quality assurance of forecasting of the investment volume model

\begin{tabular}{|c|c|c|c|c|c|c|c|c|c|c|c|c|c|c|c|c|}
\hline & \multicolumn{16}{|c|}{ Indicators } \\
\hline Real data & $\begin{array}{l}\triangleright \\
\infty \\
0\end{array}$ & 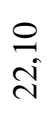 & $\stackrel{p}{q}$ & $\begin{array}{l}8 \\
\infty \\
\infty \\
\end{array}$ & $\begin{array}{l}\triangleright \\
\infty \\
\hat{D}^{0} \\
\end{array}$ & $\begin{array}{l}i n \\
i\end{array}$ & $\begin{array}{l}\infty \\
\infty \\
\infty \\
0\end{array}$ & $\frac{2}{2}$ & $\begin{array}{l}q \\
q \\
q\end{array}$ & $\begin{array}{l}q \\
\substack{q \\
m}\end{array}$ & $\begin{array}{l}\infty \\
\infty \\
\infty \\
\infty\end{array}$ & $\begin{array}{l}\stackrel{R}{2} \\
\dot{f} \\
m\end{array}$ & $\underset{i}{8}$ & $\stackrel{8}{0}$ & $\begin{array}{l}\stackrel{O}{d} \\
\stackrel{+}{d}\end{array}$ & $\begin{array}{l}8 \\
\infty \\
i\end{array}$ \\
\hline $\begin{array}{l}\text { Data predicted by } \\
\text { the network }\end{array}$ & $\begin{array}{l}\stackrel{P}{0} \\
\stackrel{0}{0}\end{array}$ & in & 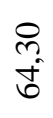 & $\begin{array}{l}n \\
\infty \\
\infty \\
n \\
n\end{array}$ & $\begin{array}{l}8 \\
\mathbb{b} \\
\stackrel{0}{0} \\
\text { in }\end{array}$ & $\underset{+}{\stackrel{f}{+}}$ & $\begin{array}{l}\text { î } \\
\infty \\
\infty \\
0\end{array}$ & 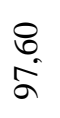 & \begin{tabular}{l}
$\infty$ \\
\multirow{r}{*}{} \\
$\sim$
\end{tabular} & 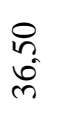 & ते & $\begin{array}{l}\mathbb{N} \\
\stackrel{f}{n} \\
m\end{array}$ & $\stackrel{5}{\rightarrow}$ & $\begin{array}{l}\infty \\
\infty \\
0\end{array}$ & $\begin{array}{l}\overrightarrow{0} \\
\dot{\sim}\end{array}$ & i. \\
\hline Deviation & $\overrightarrow{0}$ & \begin{tabular}{l}
\multirow{+}{*}{} \\
i
\end{tabular} & 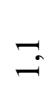 & $\stackrel{2}{8}$ & ô & $\overrightarrow{0}$ & $\ddot{0}_{0}^{\circ}$ & $\vec{i}$ & $\frac{1}{0}$ & $\stackrel{\sigma}{-}$ & ث্) & $\begin{array}{l}\text { ô. } \\
\text { î }\end{array}$ & 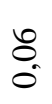 & $\overrightarrow{0}$ & oे & ô \\
\hline
\end{tabular}


Symbols in the table:

1 - investments in mine winders;

2 - investments in fan units;

3 - investments in compressor units;

4 - investments in pump stations;

5 - investments in transport installations;

6 - investments in decontamination plants;

7 - investments in thermal power units;

8 - investments in the mine surface plant;

9 - investments in electrical installations;

10 - investments in other capital investments;

11 - portfolio investments;

12 - intangible investments.

Consequently, the level of investment obtained as a result of the modeling almost coincides with the actual data, taking into account a slight deviation.

Graphically, the result of testing the neural network is shown in fig. 3, which represents the coincidence of the line of real and predicted data.

So, we can conclude that a trained neural network of "investment volume determination" can show high accuracy of the investments modeling for mines in Ukraine with minimum error rate.

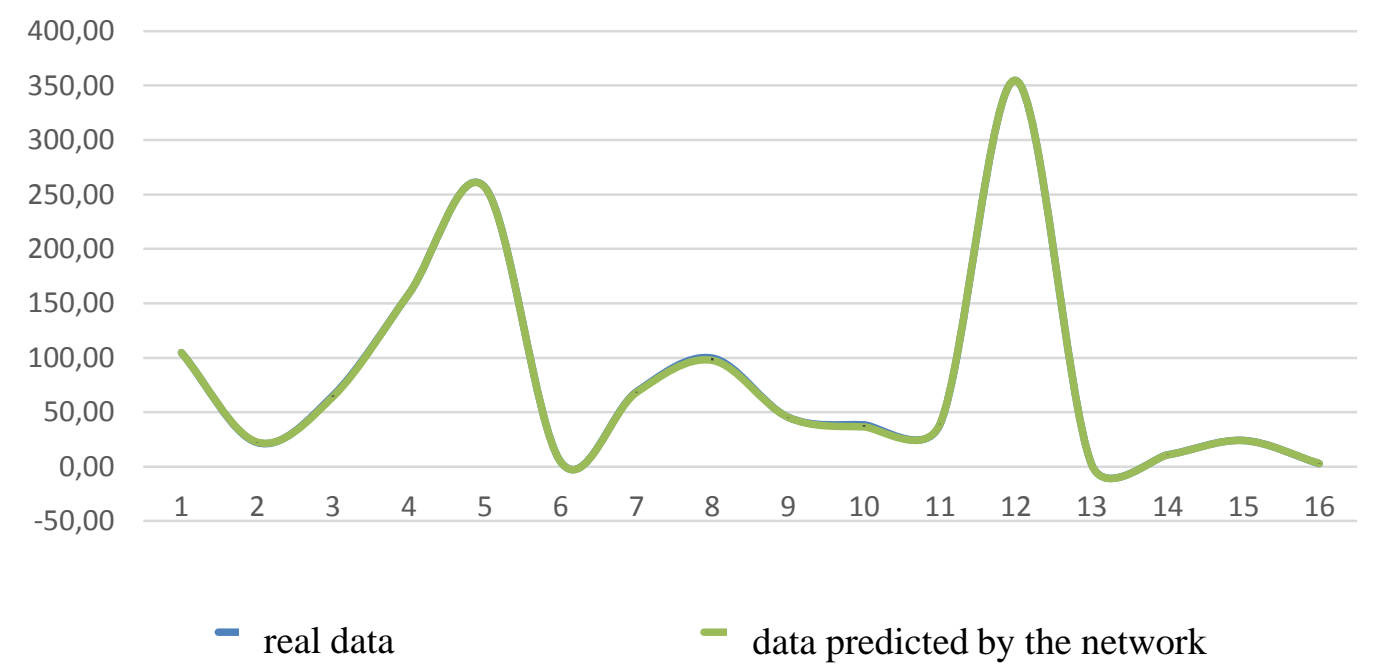

Fig. 3. Research results of modeling properties of neural network modeling for investment volumes

Source: compiled by authors

In order to test the "Modeling of mine profit from investments" neural network, developed in paragraph 2.2.2. the inputs of the network were prepared, among which there are value of investments by type (material, financial, intangible), technical properties and geological factors of coal at OJSC "Pavlogradvygillya" in 2012. With the help of the NeuroExcel add-in, based on the already trained neural network, the modeled output data was received, including the level of profit, which is 52106.4 thousand UAH, the real profit received by OJSC "Pavlogradvygillya" is 52089.00 thousand UAH. The deviation of the real indicator from the modeled one was 17.4 thousand UAH, which is an error of only $0.00028 \%$. 
Churikanova, O. and Lysenko, M. (2019). "Optimization management of investment for coal mines based on neural network model", Management and entrepreneurship: trends of development, 3(09), pp. 33-51. DOI: https://doi.org/10.26661/2522-1566/2019-3/09-03

\section{Optimization of investment}

For the formulation and solution of an optimization task, the purpose of which is to maximize profits of a coal mining enterprise, the already built economic and mathematical models based on the application of neural networks have been taken as the basis:

- a model for determining the amount of investment in a coal mining enterprise;

-economic-mathematical model for determining the profit of a coal mine from investments.

Thus, the optimization task is a synthesis of the developments on the above-mentioned models in order to maximize profits.

In the set task of optimization it is chosen:

unknown $x 1$ - $x 12$ - standardized by (2) the value of investment in: investments in mine winders $(X 1)$; investments in fan units $(X 2)$; investments in compressor units $(X 3)$; investments in pump stations $(X 4)$; investments in transport installations $(X 5)$; investments in decontamination plants $(X 6)$; investments in thermal power units $(X 7)$; investments in the mine surface plant $(X 8)$; investments in electrical installations (X9); other capital investments (X10); portfolio investments (X11); intangible investments (X12).

The average indicators of coal technical characteristics and geological factors are constant values according to a separately investigated coal-mining enterprise, that is standardized for (2): residual reserves in million tonnes (X13), average geological thickness of the coal seams (X14), maximum operating depth in meters $(X 15)$, length of mine workings in $\mathrm{km}(X 16)$, incident angle of the coal seams $(X 17)$, production (designed) capacity in million tonnes per year $(X 18)$. As well as physical and mechanical parameters of coal produced at these mines: average ash content\% (X19), average moisture content\% (X20), average sulfur content\% (X21).

$$
X_{13}, X_{14}, X_{15}, X_{16}, X_{17}, X_{18}, X_{19}, X_{20}, X_{21} \text { are constants, }
$$

Target function will look like:

Limitations on:

$$
O U T \rightarrow \max .
$$

a) the total amount of investments should not exceed the amount that the coal-mining enterprise has allocated for the development of each type of investment. So:

$i=1 . .12$;

$$
\left(x_{i}-\frac{1}{2}\right) 8 \sigma x+m_{x} \leq\left(O U T-\frac{1}{2}\right) 8 \sigma y+m y,
$$

б) investment volumes by the type of investment must be inalienable:

$$
\left(x_{i}-\frac{1}{2}\right) 8 \sigma x+m_{x} \geq 0
$$

$i=1 . .12$;

в) At the request of the enterprise, additional restrictions are imposed by type of investment in case of necessity to purchase equipment, etc.:

$$
\left(x_{i}-\frac{1}{2}\right) 8 \sigma x+m_{x} \leq Z_{i},
$$

$i=1 . .12$,

where $Z_{i}$ - amount of investment that an enterprise needs to invest in a certain type of investment.

As a result of solving the optimization task, the amount of investment investment for each type of investment is found, which increases the profit of the considered enterprise. Thus, the 
solution of the optimization task makes possible to make an investment plan for a specific coal mining enterprise, taking into account the peculiarities of its work and the experience of other mines in Ukraine. The solution of this optimization task can be done using Microsoft Excel tools, which is convenient for mining enterprise management that has only Microsoft Office programs.

The calculations were performed using Excel spreadsheets by the Newton method. The optimal investment project for OJSC "Pavlogradvygillya" for one year was calculated, using the model of determining the optimal investment volumes presented in table 3.

Table 3

The optimal investment plan for a coal mine

\begin{tabular}{|l|c|}
\hline \multicolumn{1}{|c|}{ Investments by type } & Thousand UAH \\
\hline Mine winders & 58,4 \\
\hline Fan units & 46,7 \\
\hline Compressor units & 35,1 \\
\hline Pump stations & 31,2 \\
\hline Transport installations & 50,6 \\
\hline Decontamination plants & 31,2 \\
\hline Thermal power units & 39 \\
\hline Mine surface plant & 50,6 \\
\hline Electrical installations & 46,7 \\
\hline Other capital investments & 146,1 \\
\hline Investment portfolio & 92,1 \\
\hline Intangible investments & 29,2 \\
\hline Total: & 656,9 \\
\hline
\end{tabular}

\section{RESULTS AND DISCUSSIONS}

Based on the results of the allocation of investment resources identified in the solution of the optimization task, the total amount of investments for 2012 amounted to 656.9 thousand UAH, which is 66.9 thousand UAH. more than suggested by the company's management. Moreover, the model proposed to increase the investment of money in research and development, training, securities. According to the main types of equipment, the model provides the same investment amounts as in the investment project of "Pavlogradvygillya" OJSC. Reduction of investments by the model is proposed in direction of other capital investments and for certain types of equipment. The financial indicators proposed by the neural network and obtained as a result of the implementation of the investment project of the company with the definition of absolute growth, are given in Table 4.

Table 4

Dynamics of the main financial indicators as a result of the investment project implementation, UAH ths.

\begin{tabular}{|c|c|c|c|c|c|c|}
\hline & FI & PFI & FIE $_{1}$ & FIM $_{2}$ & AGE & AGM \\
\hline Profit & 2011. & 2012 & 2012, & & & \\
\hline
\end{tabular}

where:

FI - financial indicators;

PFI - planned financial indicators;

$\mathrm{FIE}_{1}$ - financial indicators received by the neural network as a result of the implementation of the investment project proposed by the enterprise; 
Churikanova, O. and Lysenko, M. (2019). "Optimization management of investment for coal mines based on neural network model", Management and entrepreneurship: trends of development, 3(09), pp. 33-51. DOI: https://doi.org/10.26661/2522-1566/2019-3/09-03

$\mathrm{FIM}_{2}$ - financial indicators for 2012, obtained as a result of the investment project implementation after solving the optimization task;

AGE - absolute growth from the realized investment project planned by the enterprise;

AGM - the absolute growth from the investment project implementation after solving the optimization task.

Perform a comparison. As can be seen from Table. 4, both investment projects - the optimization investment project and the plan of management of the coal mining enterprise - proved to be effective and have a positive impact on the increase of the main financial indicators compared to the previous ones in 2011. But the project, obtained as a result of the solution of the optimization problem, more intensively affects the increase of the main financial indicators of the coal mining enterprise. The profit, obtained as a result of the investment project of the enterprise, amounted to 2270,00 thousand UAH, and the resulting optimization distribution of investment resources 2523,00 thousand UAH, thus the amount of the economic effect was 253,00 thousand UAH.

In order to test the methodology for determining effective investment volumes, the classical methodology for evaluating the effectiveness of investment projects was used [16-21]. The following set of indicators was used:

1. The present value (PV) is calculated for the constant discount interest by the formula:

$$
\mathrm{PV}=\sum_{t} \frac{P_{t}}{(1+r)^{t}}
$$

where:

$P t-$ cash receipts for a selected time period,

$r$ - discount interest.

$$
\mathrm{PV}=2523.0 /(1+20 \%)=2102.5 \text { thousand } \mathrm{UAH}
$$

2. Net present value (NPV) is defined as the amount of streaming effects (i.e., exceeding revenue over expenses) for the entire estimated project period over those in the beginning of the project:

$$
\mathrm{NPV}=\sum_{t} \frac{P_{t}-I C_{t}}{(1+r)^{t}}
$$

where:

ICt is the investment (expenses) made during a selected time period.

If NPV value is positive at a given discount interest (NPV>0), the project can be considered effective and consider its acceptance or further analysis. The higher the NPV value is, the more effective the project is. If NPV $<0$, then the project is considered ineffective.

$$
\mathrm{NPV}=(2523-656,9) /(1+20 \%)=8886,19
$$

3. The index of return on investment (RI) is the ratio of the sum of these effects to the investment volume, i.e.:

$$
\mathrm{PI}=\sum_{t} \frac{P_{t}}{(1+r)^{t}} / I C
$$


The return on investment index (index of profitability) is closely related to the NPV: if NPV value is positive, then $\mathrm{RI}>1$, and vice versa. Thus, if $\mathrm{RI}>1$, then the project is considered effective, and if $\mathrm{RI}<1$ - it is ineffective.

$$
\mathrm{PI}=(2523 /(1+20 \%)) / 656,9=18,28
$$

4. The internal rate of return (IRR) is the norm of the $r$ discount when NPV $=0$ (this means that the size of the consolidated effects is equal to the consolidated investment), which is determined by the formula:

$$
\mathrm{IRR}=\sum_{t} \frac{I C_{t}}{(1+r)^{t}}
$$

The NPV value of the investment project reflects its efficiency at a given predetermined rate of the $\mathrm{r}$ discount, and the IRR is determined by the method of successive approximations and compared with the required rate of return on investment. If the IRR value is not less than the required return on investment, then the investments are worthwhile. Otherwise, the project is rejected.

With the IRR indicator, the maximum relative cost level acceptable for the analyzed project can be determined. For example, if the project is fully funded by a commercial bank loan, the IRR value indicates the upper limit of the acceptable level of the bank interest rate, the excess of which turns the project into an unprofitable one.

$$
\mathrm{IRR}=\frac{656.9}{1+20 \%}=3128 \text { thousand UAH }
$$

5. The account rate of return (ARR) is the ratio of the average annual net profit of the project Pcp (balance profit minus deductions to the budget) to the average annual amount of investment ICcp (without residual or liquidation value):

$$
\mathrm{ARR}=\frac{P_{\mathrm{cp}}}{I C_{\mathrm{cp}}} \cdot 100 \%
$$

The ARR indicator is calculated without discounting costs and profits, so it does not allow to consider the difference between projects with similar annual average profits, but those that vary in time.

$$
\operatorname{ARR}=(2523 / 656,9) \cdot 100 \%=3,84
$$

6. The payback period $(P P)$ is the minimum time interval (from the beginning of the project), beyond which the integral return on the project becomes positive and remains the same. In other words, it is a period of time from which initial investments and other costs associated with the project are covered by the results. The sequence of calculating the payback period depends on the uniformity of distribution of the estimated return on investment. If the profit is distributed over the years evenly, then it is proposed to use the following formula:

$$
P P=\sum_{t} \frac{I C_{t}}{P_{t}^{\prime}}
$$


Churikanova, O. and Lysenko, M. (2019). "Optimization management of investment for coal mines based on neural network model", Management and entrepreneurship: trends of development, 3(09), pp. 33-51. DOI: https://doi.org/10.26661/2522-1566/2019-3/09-03

where:

$P_{t}^{\prime}$ is the annual profit from capital.

$$
\mathrm{PP}=656,9 / 2523=0,26
$$

Thus, based on the calculation of the efficiency of an investment project using the classical methodology for assessing the investments efficiency, we can conclude that, in accordance with all of the above indicators, the project proved to be effective.

\section{CONCLUSIONS}

The authors received a number of important results that make up the scientific novelty of the work.

For the first time: theoretical aspects of management of investment activity at the coal mining enterprise, which are reflected in the complex of economic and mathematical models, which include determination of profit of the mine from the realization of the investment project, determination of necessary investment volumes and optimization of their distribution on the criterion of profit maximization, are developed;

Improved:

- $\quad$ a model for determining the effectiveness of investments, which allows to determine the profit of the coal mining enterprise from the implementation of the investment project. Unlike existing ones, the model takes into account a group of factors inherent in the coal mining industry itself, such as geological factors and technical characteristics of coal;

- - the model of the neural network, which performs the definition of necessary investments in a coal mine at the expense of its own funds in conditions of uncertainty, which, unlike existing ones, takes into account geological factors and technical characteristics of coal;

- a model for optimizing the distribution of investments in a coal mine, which, unlike the existing ones, determines the optimal volumes of investment that help maximize profits not only by types of investments (tangible, financial, intangible), but also by 12 kinds of investments ( 9 kinds of investments in equipment, investments in capital investments, securities portfolio, intangible investments), which are most characteristic for a coal mining enterprise;

Got further development: the classification of factors that influence the efficiency of investment projects in coal mining enterprises, to which, in addition to the existing ones, technical characteristics of coal have been added.

\section{REFERENCES}

Afonin, I. V. (2006). Innovacionnyj menedzhment i jekonomicheskaja ocenka real'nyh investicij [Innovation management and economic evaluation of real investments: a training manual], Moscow, Russia (in Russian).

Amosha, A. I. and Birinberg, B. M. (1999), Ugol'naja promyshlennost' Ukrainy: problemy i reshenija [Coal industry of Ukraine: problems and solutions], IEC National Academy of Sciences of Ukraine, Donetsk, Ukraine (in Russian).

Blank, I. A. (2007). Finansovyj menedzhment [Financial Management], Kiev, Ukraine (in Russian).

Bocharov, V. V. (2000). Investicionnyj menedzhment [Investment Management], St. Petersburg, Russia (in Russian).

Bryntsev, A. N. (2012). Investicionnyj proekt: da ili net [Investment project. Yes or no], Moscow, Russia (in Russian). 
Damodaran, A. (2016). Investicionnaja ocenka. Instrumenty i metody ocenki ljubyh aktivov [Investment valuation. Tools and techniques for determining the value of any asset], , Moscow, Alpina Publisher, Russia (in Russian).

Maidukova, S. S. (2010), "On the question of investment in coal mines". Economic Bulletin Donbass, Vol. 1 Issue 19, pp. 44-49 (in Russian).

Marenkov, N. L. (2007). Osnovy upravlenija investicijami [Fundamentals of investment management], Moscow, Russia (in Russian).

Pavlenko, I.I. (2006), "On the problem of assessing the investment attractiveness of mines", materialy mizhnarodnoi naukovo-praktychnoi konferentsii [Materials of the international scientific-practical conference], Problemy i perspektyvy innovatsijnoho rozvytku ekonomiky Ukrainy [Problems and prospects of innovative development of economy of Ukraine], Dnipropetrovsk, Ukraine, pp.194-195 (in Russian).

Pavlenko, I.I. (2007), Management of investment processes in the coal industry of Ukraine, National Mining University, Dnipro, Ukraine (in Russian).

Purayev, A. (2011). Kompromissnaja ocenka jeffektivnosti investicionnyh proektov. Issledovanie i razrabotka [Compromise assessment of the effectiveness of investment projects. Research and development], LAP LAMBERT Academic Publishing (in Russian).

Qi, L. and Sun, J. (1993). "A nonsmooth version of Newton's method", Mathematical Programming, Hong Kong, China, pp. 353-367. Available at: https://doi.org/10.1007/bf01581275

Stanislavchik, E.N. (2001), Biznes-plan. Upravlenie investicionnymi proektami [Business plan. Management of investment projects], Moscow, Os'-89, Russia (in Russian).

Stanislavchik, E.N. (2017), Biznes-plan: Finansovyj analiz investicionnogo proekta [Business plan: Financial analysis of investment project], Moscow, Os'-89, Russia (in Russian).

Sutskever, I., Martens, J., Dahl, G., and Hinton G. (2013). "On the importance of initialization and momentum in deep learning", Proceedings of the 30th International Conference on Machine Learning, PMLR, 28(3), pp.1139-1147

Trifonova, E.V. and Skazhenik, Yu.B. (2005). "To the definition of the "price" of the parameters forming the level of economic reliability of the coal mine", Economics: problems of theory and practice, Dnepropetrovsk, Vol. 204, Issie IV, pp. 1054-1063 (in Russian).

Vakhrin, P.I. (2002). Investicii [Investments], Moscow, Russia (in Russian).

Vilensky, P.L., Livshits, V.N. and Smolyak, S.A. (2001). Ocenka jeffektivnosti investicionnyh proektov. Teorija i praktika. [Evaluation of the effectiveness of investment projects: theory and practice: a practical training manual], Moscow, Russia (in Russian).

Vorontsovsky, A.V. (2003). Investicii i finansirovanie. Metody ocenki i obosnovanija [Investments and financing. Assessment and justification methods], St. Petersburg University, Moscow, Russia (in Russian).

Zell, A. (2001). Biznes-plan: investicii i finansirovanie, planirovanie i ocenka proektov [Businessplan: investments and financing, project planning and evaluation], Moscow, Russia (in Russian).

\section{СПИСОК ВИКОРИСТАНИХ ДЖЕРЕЛ}

Афонин И. В. Инновационный менеджмент и экономическая оценка реальных инвестиций: учебное пособие. Москва: Гардарики, 2006. 301 с.

Амоша А. И., Биринберг Б.М. Угольная промышленность Украины: проблемы и решения. Донецк: ИЭП НАН Украины, 1999. 96 с.

Бланк И. А. Финансовый менеджмент. 2-е изд., перераб. и доп. Киев: Эльга Ника-Центр, 2007. $521 \mathrm{c}$.

Бочаров В. В. Инвестиционный менеджмент. Санкт-Петербург: Питер, 2000. 160 с. 
Churikanova, O. and Lysenko, M. (2019). "Optimization management of investment for coal mines based on neural network model", Management and entrepreneurship: trends of development, 3(09), pp. 33-51. DOI: https://doi.org/10.26661/2522-1566/2019-3/09-03

Брынцев А. Н. Инвестиционный проект: да или нет: Учебно-методическое пособие. Москва: Издательский дом «Экономическая газета», 2012. 126с.

Дамодаран А. Инвестиционная оценка. Инструменты и методы оценки любых активов. Москва: Альпина Паблишер, 2016. 1316 с.

Майдукова С. С. К вопросу инвестиций в угольные шахты. Економічний вісник Донбасу. 2010. № 1 (19). С. 8-11.

Маренков Н.Л. Основы управления инвестициями. Москва, 2007. 480 с.

Павленко И. И. К проблеме оценки инвестиционной привлекательности шахт. Проблеми $i$ перспективи інновачійного розвитку економіки України: матеріали міжнародної науково-практичної конференції, Д.: НГУ, 2006. С. 194-195.

Павленко И. И. Управление инвестиционным процессом в угольной промышленности Украины: монография. Национальный горный ун-т. Днепропетровск, 2007. 235 с.

Пуряев А.С. Компромиссная оценка эффективности инвестиционных проектов. Исследование и разработка - LAP LAMBERT Academic Publishing, 2011. - 276 c.

Qi, L. and Sun, J. (1993). "A nonsmooth version of Newton's method", Mathematical Programming, Hong Kong, China, pp. 353-367. Available at: https://doi.org/10.1007/bf01581275

Станиславчик Е. Н. Бизнес-план. Управление инвестиционными проектами. Москва: Ось-89, 2001. $128 \mathrm{c}$.

Станиславчик Е.Н. Бизнес-план: Финансовый анализ инвестиционного проекта. Москва: Jcm-89, 2001. 96 c.

Sutskever, I., Martens, J., Dahl, G., and Hinton G. (2013). "On the importance of initialization and momentum in deep learning", Proceedings of the 30th International Conference on Machine Learning, PMLR, 28(3), pp.1139-1147

Трифонова Е.В., Скаженик Ю.Б. К определению «цены» параметров, формирующих уровень экономической надежности угольной шахты. Економіка: проблеми теорї та практики. Д. 2005. Вип. 204, т. 4. С. 1054-1063

Вахрин П.И. Инвестиции. Учебник. М.: Издательско-торговая корпорация «Дашков и К», 2002. $384 \mathrm{c}$.

Виленский П.Л, Лившиц В.Н, Смоляк С.А. Оценка эффективности инвестиционных проектов. Теория и практика. 2-е изд., перераб. и доп. Москва: Дело, 2002. 888 с.

Воронцовский А. В. Инвестиции и финансирование. Методы оценки и обоснования. Москва. 2003. 528c.

Зелль А. Бизнес-план: инвестиции и финансирование, планирование и оценка проектов. Москва: Ось-89, 2001. 240с.

\section{ОПТИМІЗАЦІЯ УПРАВЛЯННЯ ІНВЕСТИЦІЯМИ НА ВУГІЛЬНІЙ ШАХТІ ІЗ ЗАСТОСУВАННЯМ МОДЕЛІ НЕЙРОННИХ МЕРЕЖ}

\author{
Чуріканова Олена Юріївна \\ НТУ «Дніпровська політехніка» \\ Дніпро, Україна
}

\author{
Лисенко Марина Олександрівна \\ Запорізький національний університет \\ Запоріжжя, Украӥна
}

Основна мета статті полягає у розробці концептуальних положень та системи економіко-математичних моделей управління інвестиційною діяльністю вуглевидобувного підприємства, включаючи вдосконалення принципів i методів аналізу прибутковості інвестиційних проектів та оптимального розподілу інвестицій. Виходячи з цього, у статті обгрунтована необхідність вирішення таких питань:

- визначити цілі інвестиційної діяльності на вуглевидобувних підприємствах;

- систематизувати й визначити статистично значимі фактори, які впливають на інвестиційну діяльність на вуглевидобувних підприємствах; 
- сформувати економіко-математичну модель визначення обсягів інвестування з метою отримання суми, яку вуглевидобувне підприємство спроможне виділити на інвестування;

- сформувати економіко-математичну модель визначення прибутку підприємства у результаті реалізації інвестиційного проекту.

- показати доцільність і перспективність впровадження розробленого комплексу моделей, перевірити їх практичну ефективність.

За допомогою нейронних сіток було побудовано модель за 12-ма видами інвестування (9 видів інвестицій в обладнання, інвестиції у капітальні вкладення, у портфель цінних паперів, нематеріальні інвестиції), що $є$ найбільш характерними для вуглевидобувного підприємства. Розроблено методику оптимізації розподілу інвестицій на вугільній шахті, яка на відміну від існуючих визначає оптимальні обсяги інвестування, що сприяють максимізації прибутку за 12-ма моделями інвестування. Створені в ході дослідження економічні та математичні моделі вирішують наступні питання:1) аналіз впливу геологічних факторів та технічних характеристик вугілля на ефективність роботи вугледобувного підприємства та на ефективність інвестицій; 2) аналіз впливу обсягів 12 видів інвестицій на рівень прибутку вугільної шахти; 3) визначення суми, яку вугільна шахта може виділити на інвестування за власні кошти; 4) визначення прибутку від певного інвестиційного проекту з урахуванням усіх вищезазначених параметрів; 5) можливість коригування інвестиційного проекту з метою отримання максимального прибутку.

Ключові слова: вугільна промисловість, інвестиції, статистично значущі фактори, економіко-математичні моделі, нейронні мережі, оптимізація.

\section{ОПТИМИЗАЦИЯ УПРАВЛЕНИЯ ИНВЕСТИЦИЯМИ НА УГОЛЬНОЙ ШАХТЕ С ПРИМЕНЕНИЕМ МОДЕЛИ НЕЙРОННОЙ СЕТИ}

\author{
Чуриканова Елена Юрьевна \\ НТУ «Днепровская политехника» \\ Днепр, Украина
}

\author{
Лысенко Марина Александровна \\ Запорожский национальный университет \\ Запорожье, Украина
}

Основная цель статьи заключается в разработке концептуальных положений и системы экономико-математических моделей управления инвестиционной деятельностью угледобывающего предприятия, включая совершенствование принципов и методов анализа прибыльности инвестиционных проектов и оптимального распределения инвестиций. Исходя из этого, в статье обоснована необходимость решения следующих вопросов:

- определить цели инвестиционной деятельности на угледобывающих предприятиях;

- систематизировать и определить статистически значимые факторы, влияющие на инвестиционную деятельность на угледобывающих предприятиях;

- сформировать экономико-математическая модель определения объемов инвестирования с целью получения суммы, которую угледобывающее предприятие способно выделить на инвестирование;

- сформировать экономико-математическая модель определения прибыли предприятия в результате реализации инвестиционного проекта.

- показать целесообразность и перспективность внедрения разработанного комплекса моделей, проверить их практическую эффективность.

С помощью нейронных сетей была построена модель по 12-ти видам инвестирования (9 видов инвестиций в оборудование, инвестиции в капитальные вложения, в портфель ценных бумаг, нематериальные инвестиции), являются наиболее характерными для угледобывающего предприятия. Разработана методика оптимизации распределения инвестиций на угольной шахте, в отличие от существующих определяет оптимальные объемы инвестирования, способствующих максимизации прибыли за 12-ю моделями 
Churikanova, O. and Lysenko, M. (2019). "Optimization management of investment for coal mines based on neural network model", Management and entrepreneurship: trends of development, 3(09), pp. 33-51. DOI: https://doi.org/10.26661/2522-1566/2019-3/09-03

инвестирования. Созданные в ходе исследования экономические и математические модели решают следующие вопросы: 1) анализ влияния геологических факторов и технических характеристик угля на эффективность работы угледобывающего предприятия и на эффективность инвестиций; 2) анализ влияния объемов 12 видов инвестиций на уровень прибыли угольной шахты; 3) определение суммы, которую угольная шахта может выделить на инвестирование за собственные средства; 4) определение прибыли от определенного инвестиционного проекта с учетом всех вышеупомянутых параметров; 5) возможность корректировки инвестиционного проекта с целью получения максимальной прибыли.

Ключевые слова: угольная промышленность, инвестиции, статистически значимые факторы, экономико-математические модели, нейронные сети, оптимизация. 